Check for updates

Cite this: J. Mater. Chem. B, 2020 8,7548

Received 4th April 2020,

Accepted 16th June 2020

DOI: 10.1039/d0tb00894j

rsc.li/materials-b

\section{A cerium-based MOFzyme with multi-enzyme-like activity for the disruption and inhibition of fungal recolonization $\dagger$}

\author{
Hani Nasser Abdelhamid, (DD *a Ghada Abd-Elmonsef Mahmoud (D) ${ }^{b}$ and \\ Walid Sharmouk ${ }^{c}$
}

\begin{abstract}
A cerium-based metal-organic framework (Ce-MOF, denoted as AU-1) was synthesized using a solvothermal method by employing 4,4',4" -nitrilotribenzoic acid $\left(\mathrm{H}_{3} \mathrm{NTB}\right)$ as the linker and cerium clusters as the metal center. The material was considered as a MOFzyme based on the peroxidase-like activity of Ce-MOF that could eliminate and kill fungi, such as Aspergillus flavus, Aspergillus niger, Aspergillus terreus, Candida albicans, and Rhodotorula glutinis. Ce-MOF showed high antifungal activity against airborne opportunistic human pathogens isolated from the outside of a hospital. The antifungal activity of CeMOF was evaluated using the colony-forming units, dry mass method, soluble proteins, and microscopic imaging. It exhibited an inhibition efficiency of $93.3-99.3 \%$ based on the colony-forming unit method. The Ce-MOF caused extensive deformation of the conidiophores, vesicles, and phialides with growth inhibition between 7.55-77.41\% (based on the dry mass method). Ce-MOF showed different efficiencies in inhibiting the different fungal species. The biological activity of Ce-MOF was due to its enzymatic activity, such as those of antioxidants, catalase, superoxide dismutase, and peroxidase. Ce-MOF exhibited excellent enzymatic activity towards the fungal cells. Our results may facilitate the design of a MOFzyme system and pave the way for more profound applications of nanozymes.
\end{abstract}

\section{Introduction}

Metal-organic frameworks (MOFs) $)^{1,2}$ are fascinating porous materials with unique properties compared with other families of porous materials. $^{3-12}$ They have several advanced applications, ${ }^{13-21}$ including MOF-based nanozymes (MOFzymes). MOFzymes are promising for applications, such as sensing and cancer therapy, ${ }^{22}$ and biomimetic catalysts. ${ }^{3}$ MOFzymes demonstrate significant advantages, such as facile synthesis procedure, low price, long-term storage stability, and high environmental stability. ${ }^{23}$ Several MOFs, including cerium-based MOFs, have been reported with enzymatic properties. It has been reported that ligand metal charge transfer (LMCT) is favorable only in Ce-based MOFs. ${ }^{4}$ A Ce-based MOF has been reported as an enzyme with deoxyribonuclease (DNase)- and peroxidase-mimetic

\footnotetext{
${ }^{a}$ Advanced Multifunctional Materials Laboratory, Department of Chemistry, Faculty of Science, Assiut University, Assiut 71516, Egypt.

E-mail: hany.abdelhamid@aun.edu.eg

${ }^{b}$ Department of Botany \& Microbiology, Faculty of Science, Assiut University, Assiut 71516, Egypt

${ }^{c}$ National Research Centre, Department of Inorganic Chemistry, Tahrir St, Dokki, 12622 Giza, Egypt

† Electronic supplementary information (ESI) available. See DOI: 10.1039/ dotb00894j
}

activities that could combat biofilms. ${ }^{24}$ Cerium (Ce)-doped zeolitic imidazolate framework-8 (ZIF-8) showed simultaneous antibacterial and anti-inflammatory capabilities. ${ }^{25}$ A mixed-valence Ce-MOF (Ce-BPyDC) was applied for ascorbic acid (AA) detection using a sensitive and selective colorimetric method. ${ }^{26}$

Fungi are a heterogeneous group of microorganisms, which inhabit various environments, such as plants, debris, soils, rivers, lakes, seas and even extreme environments. ${ }^{27}$ They release their spores into the air and thus can be called as airborne fungi. ${ }^{28}$ Inhalation of hyphal fragments, spores, and by-products of fungi by human leads to serious respiratory problems, and may cause asthma. ${ }^{29}$ The airborne fungal spores pose a huge risk to human health, especially immunocompromised individuals and allergy-prone people, ${ }^{29}$ especially hospitalised patients, who are very susceptible to the infections caused by the spores. ${ }^{30}$ Aspergillus is a well-known opportunistic human pathogen associated with aspergillosis, allergy, asthma, rhinitis, and conjunctivitis. ${ }^{31}$ Aspergillus strains, such as Aspergillus flavus, have been reported as causal agents of aspergillosis, keratitis, otitis, invasive sinusitis, and other systemic infections. ${ }^{32}$ Yeasts, such as Candida albicans, colonize the skin and gastrointestinal tract of human as opportunistic pathogens. $^{33}$ Nanotechnology has been employed in several advanced applications, including the development of antimicrobial 
agents. ${ }^{34-41}$ Nanoparticles exhibit high potential in the treatment of gastrointestinal tract ${ }^{42}$ and as antimicrobial materials against resistant microbial infections.

Herein, a new cerium-based MOF, AU-1 (referring to Assiut University-1), was synthesized using a solvothermal method. The crystallinity and phase purity of the synthesized material was confirmed using X-ray diffraction (XRD). The chemical bonds and coordination within the frame were verified via Fourier transform infrared spectroscopy (FT-IR) and X-ray photoelectron spectroscopy (XPS). The morphology and particle size were estimated using transmission electron microscopy (TEM), highresolution TEM (HR-TEM), and scanning electron microscopy (SEM). According to the thermal analysis performed using thermogravimetric analysis (TGA) and differential thermal analysis (DTA), AU-1 exhibited high thermal stability. The Ce-MOF showed enzyme-mimicking activities and offered promising biological activity against airborne opportunistic fungi. It caused deformation and oxidative stress in the investigated fungal cells.

\section{Materials and methods}

Aluminum chloride anhydrous $\left(\mathrm{AlCl}_{3}\right)$, triphenylamine, $\mathrm{CH}_{2} \mathrm{Cl}_{2}$, $\mathrm{Na}_{2} \mathrm{SO}_{4}$, 1,4-dioxane, bromine, cerium nitrate, and sodium hydroxide were purchased from Sigma-Aldrich (Germany). All chemical reagents were used without purification.

\section{Synthesis of organic linker}

The synthesis of the organic linker is systematically presented in Fig. 1a. The procedure involved two steps.

Synthesis of $4,4^{\prime}, 4^{\prime \prime}$-Triacetyltriphenylamine $\left(1,1^{\prime}, 1^{\prime \prime}\right.$-[nitrilotri (4,1-phenylene)]tri(ethan-1-one)). A solution of aluminum chloride anhydrous $\left(\mathrm{AlCl}_{3}, 3.6 \mathrm{~g}, 26.9 \mathrm{mmol}\right)$ was prepared in dry $\mathrm{CH}_{2} \mathrm{Cl}_{2}(150 \mathrm{~mL})$. The solution was cooled down to $273 \mathrm{~K}$ and stirred for $20 \mathrm{~min}$. A solution of triphenylamine $(2.0 \mathrm{~g}(8.1 \mathrm{mmol})$ was dissolved in $30 \mathrm{~mL}$ of dry $\mathrm{CH}_{2} \mathrm{Cl}_{2}$ ) was added dropwise to the solution of $\mathrm{AlCl}_{3}$. The color of the solution turned deep blue. After that, a solution of acetyl chloride (prepared via mixing $3.9 \mathrm{~mL}$ $\left(56.2 \mathrm{mmol}\right.$ ) in $30 \mathrm{~mL}$ of dry $\mathrm{CH}_{2} \mathrm{Cl}_{2}$ ) was added dropwise at $273 \mathrm{~K}$.
Then, the reaction mixture was stirred for $12 \mathrm{~h}$ at room temperature. The aqueous layer was extracted with $\mathrm{CH}_{2} \mathrm{Cl}_{2}(3 \times 150 \mathrm{~mL})$ and brine. The organic layers were dried over anhydrous $\mathrm{Na}_{2} \mathrm{SO}_{4}$. The solution was concentrated under reduced pressure to give the crude product, which was purified using flash column chromatography on silica gel with hexane/ $\mathrm{CH}_{2} \mathrm{Cl}_{2}(1: 10)$ as the eluent. The purified material was obtained a yellow solid with a yield of $92 \%$ (2.8 g). ${ }^{1} \mathrm{H}$ NMR (400 MHz, $\mathrm{CDCl}_{3}$ ) chemical shift $(\delta) 7.90 \mathrm{ppm}$ $(\mathrm{d}, 6 \mathrm{H}, J=8 \mathrm{~Hz}), 7.14 \mathrm{ppm}(\mathrm{d}, 6 \mathrm{H}, J=8 \mathrm{~Hz})$, and $2.58 \mathrm{ppm}(\mathrm{s}, 9 \mathrm{H})$ (Fig. S1, ESI $\dagger$ ). $\left.{ }^{13} \mathrm{C} \mathrm{NMR} \mathrm{(100} \mathrm{MHz,} \mathrm{CDCl}_{3}\right) \delta: 196.5$ ppm, $150.3 \mathrm{ppm}$, 132.8 ppm, 130.1 ppm, 123.9 ppm, and 26.4 ppm (Fig. S2, ESI $\dagger$ ).

$\mathbf{4}, \mathbf{4}^{\prime}, \mathbf{4}^{\prime \prime}$-nitrilotribenzoic acid $\left(\mathrm{H}_{3} \mathbf{N T B}\right)$. A solution of $4,4^{\prime}, 4^{\prime \prime}$ triacetyltriphenylamine $(1.7 \mathrm{~g}, 4.7 \mathrm{mmol})$ was prepared in 1,4dioxane $(50 \mathrm{~mL})$. The solution was cooled down on an ice bath. Bromine $(2.4 \mathrm{~mL}, 47.2 \mathrm{mmol})$ was added dropwise to a solution of $\mathrm{NaOH}(6.2 \mathrm{~g}, 156.0 \mathrm{mmol})$ in $\mathrm{H}_{2} \mathrm{O}(30 \mathrm{~mL})$ cooled on an ice bath with stirring for $20 \mathrm{~min}$ and then added dropwise to the above solution. The reaction mixture was stirred at room temperature for $12 \mathrm{~h}$ at $60{ }^{\circ} \mathrm{C}$. Then, the mixture was cooled on an ice bath. A saturated solution of hydroxylamine hydrochloride was added. The solution was acidified with $\mathrm{HCl}$. A solid precipitate was filtered and dried under vacuum to afford the pure product as a yellowish-white solid. Proton nuclear magnetic resonance $\left({ }^{1} \mathrm{H} \mathrm{NMR}, 400 \mathrm{MHz}\right.$, DMSO- $\left.\mathrm{d}_{6}\right)$ chemical shifts $(\delta)$ of $12.8 \mathrm{ppm}(\mathrm{bs}, 3 \mathrm{H}), 7.92 \mathrm{ppm}(\mathrm{d}, 6 \mathrm{H}, J=8 \mathrm{~Hz})$, and $7.16 \mathrm{ppm}$ (d, $6 \mathrm{H}, J=8 \mathrm{~Hz}$, Fig. S3, ESI $\dagger$ ). ${ }^{13} \mathrm{C}$ NMR $(100 \mathrm{MHz}$, DMSO-d $_{6}$ ) $\delta: 167.2 \mathrm{ppm}, 150.3 \mathrm{ppm}, 131.6 \mathrm{ppm}, 126.4 \mathrm{ppm}$, 124.2 ppm (Fig. S4, ESI $\dagger$ ).

\section{Synthesis of the cerium-MOF}

The cerium MOF, AU-1, was synthesized using a solvothermal method (Fig. 1b). $\mathrm{Ce}\left(\mathrm{NO}_{3}\right)_{3} \cdot 6 \mathrm{H}_{2} \mathrm{O}(0.14 \mathrm{~g})$ and $4,4^{\prime}, 4^{\prime \prime}$ nitrilotribenzoic acid $\left(\mathrm{H}_{3} \mathrm{NTB}, 0.12 \mathrm{~g}\right)$ were dissolved in a mixture of DMF $(10 \mathrm{~mL}), \mathrm{H}_{2} \mathrm{O}(1 \mathrm{~mL})$, and $\mathrm{HCl}(0.1 \mathrm{M}, 2 \mathrm{~mL})$ in a sealed glass vial (Fig. 1b). The solution was sonicated for $20 \mathrm{~min}$. Then, it was heated at $85{ }^{\circ} \mathrm{C}$ for $16 \mathrm{~h}$. A yellow crystalline powder was obtained using filtration. The product was characterized using $\mathrm{XRD}$ before and after washing with DMF and ethanol $(3 \times 25 \mathrm{~mL})$.
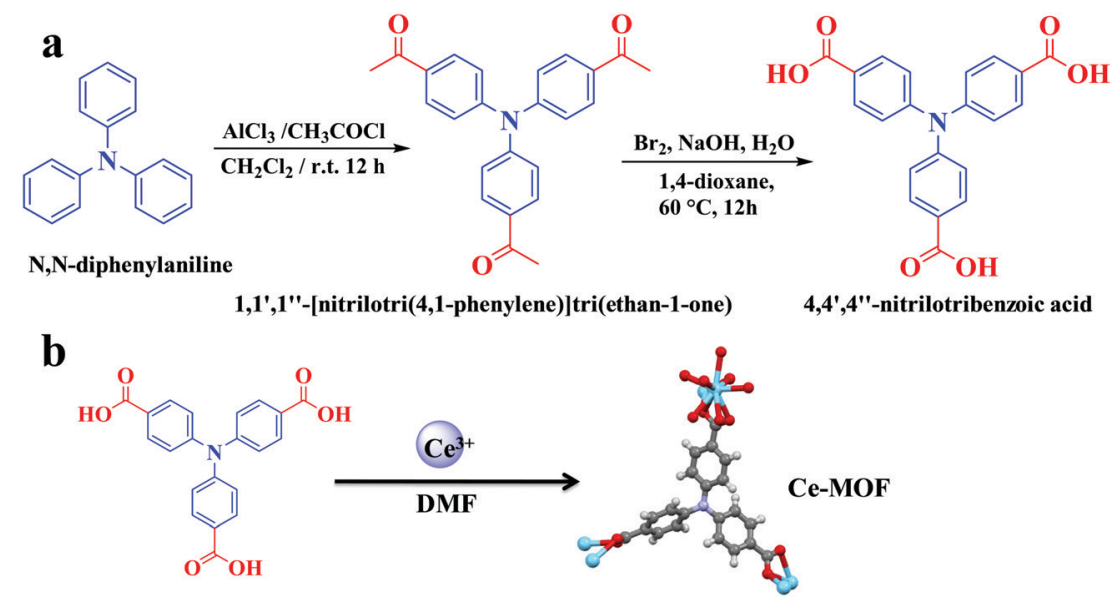

Fig. 1 Schematic representation of the synthesis of the (a) organic linker and (b) Ce-MOF AU-1. 


\section{Characterization instruments}

X-ray diffraction (XRD) was recorded using Phillips 1700 X'Pert ( $\mathrm{Cu} \mathrm{K} \mathrm{K}_{\alpha}$ radiation). The structure solution and simulation of the XRD pattern were carried out using EXPO2014 and the diffraction-crystal module of the mercury $(\mathrm{Hg})$ program version 3.1, which is available free of charge (http:/www.ccdc.cam.ac. uk). The X-ray photoelectron spectra (XPS) were recorded using a Thermo Fisher (K-alpha) instrument with monochromated micro-focused $\mathrm{Al} \mathrm{K}_{\alpha}$ radiation $(1486.6 \mathrm{eV})$. The $\mathrm{C} 1 \mathrm{~s}$ peak at $284.4 \mathrm{eV}$ was used as the reference. The transmission electron microscopy (TEM) and high-resolution TEM (HR-TEM) images were recorded using TEM-2100 (JEOL, Japan, operated at accelerating voltage $200 \mathrm{kV}$ ). Scanning electron microscopy (SEM) was performed using JSM-6010LV (JEOL, Japan). The Ce-MOF sample was coated with Pt-Pd using a JEC-3000FC auto fine coater (JEOL, Japan). Fourier transform infrared spectroscopy (FT-IR) was carried out using a Nicolet spectrophotometer (model 6700). Thermogravimetric analysis (TGA) and differential thermal analysis (DTA) were performed using a TA 60 thermal analyzer (Shimadzu, Japan) at a heating rate of $10{ }^{\circ} \mathrm{C} \mathrm{min}^{-1}$ and an airflow rate of $30 \mathrm{~mL} \mathrm{~min}{ }^{-1}$. The proton $\left({ }^{1} \mathrm{H}\right)$ and carbon $\left({ }^{13} \mathrm{C}\right)$ analyses of the organic linker were conducted on Bruker $400 \mathrm{MHz}$ instruments using the residual signals for $\mathrm{CDCl}_{3}$ at chemical shifts $(\delta)$ of $7.26 \mathrm{ppm}$ and $77.0 \mathrm{ppm}$, and for $\mathrm{DMSO}^{-\mathrm{d}_{6}}$ at $\delta=2.50 \mathrm{ppm}$ and $39.4 \mathrm{ppm}$.

\section{Microorganisms and inoculum preparation}

Aspergillus flavus (Link, Af-10), Aspergillus niger (van Tieghem, An-14), Aspergillus terreus (Thom, At-40), Candida albicans (Robin, Berkhout, Ca-6) and Rhodotorula glutinis (Fresenius, Harrison, Ro-39) were isolated from the air spores present outside of a public hospital in the Assiut Governorate using Czapek's dextrose agar medium supplemented with chloramphenicol $\left(250 \mathrm{mg} \mathrm{mL}^{-1}\right.$ ) as the bacteriostatic. The climatic conditions were $17.2 \mathrm{~km} \mathrm{~h}^{-1}$ wind speed and $36 \%$ relative humidity with the minimum and maximum temperatures of $22{ }^{\circ} \mathrm{C}$ and $26.7{ }^{\circ} \mathrm{C}$, respectively. The plates containing the medium were maintained open for 10 min outside the hospital in different places, then transferred directly to the laboratory and incubated at $28 \pm 1{ }^{\circ} \mathrm{C}$ in aerobic conditions for 7 days. The developed isolates were identified and stored at $4 \pm 1{ }^{\circ} \mathrm{C}$ on potato dextrose agar (PDA) slants. ${ }^{43}$ Before the experiment, the microbial inoculums were prepared via scraping of 5 and 3 days for Aspergillus sp. and C. Albicans or R. glutinis, respectively. The cells were cultured on PDA and suspended in sterilized distilled water fortified with $0.1 \%$ Triton X100 to at a concentration of $2 \times 10^{5}$ spore $\mathrm{mL}^{-1}$.

\section{The effect of AU-1 on the growth of opportunistic pathogenic fungi}

The Czapek's broth medium $\left(\mathrm{g} \mathrm{L}^{-1}\right.$ ) was prepared using glucose $(30.0 \mathrm{~g}), \mathrm{KH}_{2} \mathrm{PO}_{4}(1.0 \mathrm{~g})$, yeast extract $(5.0 \mathrm{~g}), \mathrm{MgSO}_{4} \cdot 7 \mathrm{H}_{2} \mathrm{O}(0.5$ $\mathrm{g}), \mathrm{NaNO}_{3}(3.0 \mathrm{~g}), \mathrm{KCl}(0.5 \mathrm{~g}), \mathrm{FeSO}_{4} \cdot 7 \mathrm{H}_{2} \mathrm{O}(0.01 \mathrm{~g})$ and distilled water $(1 \mathrm{~L})$ and autoclaved for $20 \mathrm{~min}$ at a pressure of $1.5 \mathrm{~atm}$ and a temperature of $121{ }^{\circ} \mathrm{C}$. Chloramphenicol sterilized using a
$0.22 \mathrm{~mm}$ membrane filter was added as a bacteriostatic. AU-1 (0, 10, 20, 30 and $40 \mu \mathrm{g} \mathrm{mL} \mathrm{m}^{-1}$ ) was tested in Czapek's broth (50 $\mathrm{mL})$. The inoculums $(1 \%, \mathrm{v} / \mathrm{v})$ were added and incubated at 28 $\pm 1{ }^{\circ} \mathrm{C}$ in a rotary shaker $(150 \mathrm{rpm})$ for 7 days. After fungal growth, the Aspergillus biomass was filtered using Whatman filter paper and washed twice with distilled water for drying at $70{ }^{\circ} \mathrm{C}$ in a hot air oven for dry mass estimation. ${ }^{44}$ For yeast, the biomass was collected using centrifugation (4000 rpm) for $10 \mathrm{~min}$. The harvested biomass was then washed with distilled water $(2 \times 50 \mathrm{~mL})$ to remove residues. The experiments were repeated at least three times to ensure repeatability and reproducibility.

\section{The effect of AU-1 on the morphology of pathogenic fungi}

All the cultures at different concentrations were examined using a microscope (Olympus CX41, Japan) for changes in cell morphology. Typically, samples from the growing cultures were trapped using a needle, stained with lactophenol cotton blue, and directly subjected to the microscopic imaging. The effect of the amount of Ce-MOF on the viability of the spores at the highest Ce-MOF concentration $\left(40 \mu \mathrm{g} \mathrm{mL}{ }^{-1}\right)$ was recorded by inoculating the spore suspension from the Czapek's broth culture in sterilized Czapek's agar medium and determining the viability and ability of these spores to grow again. Meanwhile, the total counts of the yeast cells and fungal spores were determined via microbial counting on a hemocytometer.

\section{Oxidative stress generated by AU-1 on the opportunistic fungi}

The culture flasks containing AU-1 and inoculums were prepared in the broth medium, as described previously. Afterward, the biomass was collected using filtration (for Aspergillus) or centrifugation (for C. Albicans, and R. glutinis). The separated biomass was washed with double distilled water $(3 \times 50 \mathrm{~mL})$ and disrupted mechanically via grinding in a cold mortar containing liquid nitrogen to ensure complete cellular breakage. The extracted cells were treated using potassium phosphate buffer supplemented with ethylenediaminetetraacetic acid (EDTA) and polyvinyl pyrrolidone (PVP, $\mathrm{pH}=7.8$ ). The microbial extracts were centrifuged at $4{ }^{\circ} \mathrm{C}(18000 \mathrm{rpm}, 10 \mathrm{~min})$. The supernatants were collected for the following biological tests: total antioxidant activity (TA), soluble proteins (SP), superoxide dismutase (SOD), catalase (CAT), and peroxidase (POD). ${ }^{45}$

\section{Analysis of enzymatic activity}

The total antioxidants were estimated using the phosphomolybdenum method at $695 \mathrm{~nm}$. The results were calculated as $\mathrm{mg} \mathrm{g}^{-1}$ soluble protein using a standard curve of ascorbic acid. ${ }^{46}$ The soluble proteins were measured using the Folin reagent method (colorimetric method using absorbance at $750 \mathrm{~nm}$ ). The amount of soluble protein $\left(\mathrm{mg} \mathrm{g}^{-1}\right)$ was calculated using a standard curve of bovine serum albumin. Superoxide dismutase (EC: 1.15.1.1) was assayed using the epinephrine autoxidation method at $480 \mathrm{~nm}$ for $1 \mathrm{~min}$. Catalase (EC: 1.11.1.6) was evaluated via the measurement of hydrogen peroxide consumption for $1 \mathrm{~min}$ at $240 \mathrm{~nm}$. Peroxidase (EC: 1.11 .1 .7 ) was determined using guaiacol $(1.5 \mathrm{mM})$ at 470 for $1 \mathrm{~min}$. All colorimetric assays were performed using a T60 UV spectrophotometer split beam. 
The effect of $\mathrm{H}_{2} \mathrm{O}_{2}$ on the UV-Vis absorption of Ce-MOF was recorded using FLAME-S-UV-VIS (200-850 nm, Rochester, NY 14607 USA). Ce-MOF ( $8 \mathrm{mg}$ ) was dispersed in deionized water $(8 \mathrm{~mL})$ using ultrasonication. Hydrogen peroxide $(0.05 \mathrm{~mL})$ was added. A UV-cuvette was filled with $4 \mathrm{~mL}$ of the solution and the UV-Vis spectra of the solution were recorded over time (0-80 $\mathrm{min})$.

\section{Results and discussion}

\section{Material characterization}

The solvothermal reaction between cerium nitrate and the tritopic carboxylate linker $\mathrm{H}_{3} \mathrm{NTB}$ (Fig. 1a) in DMF formed a Ce-MOF, namely AU-1 (Fig. 1b). The XRD of the as-synthesized Ce-MOF contained a strong diffraction Bragg's peak at $2 \theta$ around $25.3^{\circ}$, which was attributable to the linker $\mathrm{H}_{3} \mathrm{NTB}$ molecules residing inside the pores (Fig. S5, ESI $\dagger$ ). The XRD pattern of the purified and activated frameworks showed no peak for the occluded linker molecules (Fig. 2). The synthesized crystals were small-sized, making it very difficult to directly determine their crystal structure using single-crystal diffraction measurements. Therefore, we relied on powder X-ray diffraction (PXRD) analysis to elucidate the Ce-MOF structure (Fig. 2). Based on the data, the AU-1 structure was first indexed to the trigonal $R 32$ space group. ${ }^{47} \mathbf{A U}-\mathbf{1}$ crystallized in the hexagonal space group $P 6_{3} / \mathrm{mcm}$ with the following cell parameters: lengths $-a=$ 24.803 $\AA$ and $c=13.33 \AA$ and angles $-\alpha=\beta=90^{\circ}$ and $\gamma=120^{\circ} .47$

The elemental composition and chemical oxidation state of the Ce-MOF was investigated using XPS spectra (Fig. 3). The XPS survey spectrum showed peaks related to the elements $\mathrm{Ce}, \mathrm{N}, \mathrm{C}$, and $\mathrm{O}$ (Fig. 3a). The analysis of the $\mathrm{C} 1 \mathrm{~s}$ region showed peaks at the binding energies of $284.2 \mathrm{eV}, 285.7 \mathrm{eV}$, and $287.9 \mathrm{eV}$ corresponding to $\mathrm{C}-\mathrm{C}, \mathrm{C}-\mathrm{O}-\mathrm{C}$, and $\mathrm{C}-\mathrm{C}=\mathrm{O}$, respectively (Fig. 3b). The spectrum of N1s showed a peak at the binding energy of $399.5 \mathrm{eV}$ for $\mathrm{C}-\mathrm{N}$ (Fig. 3c). The analysis of the
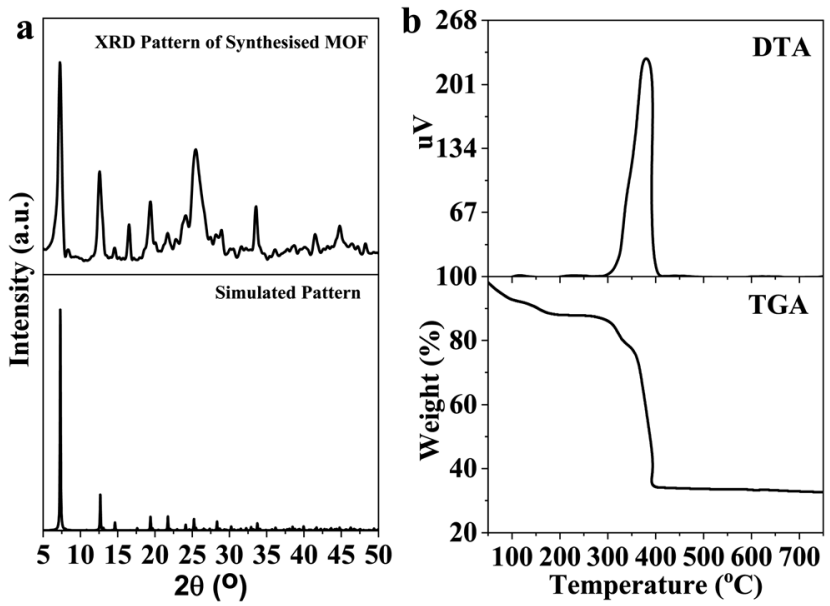

Fig. 2 (a) Simulated XRD and experimental XRD patterns of AU-1, and (b) thermal analysis using TGA and DTA. Note that the low resolution of the lab X-ray data precluded the use of Rietveld refinement to determine the atomic coordinates further accurately.
O1s spectrum showed peaks at the binding energies of $531.1 \mathrm{eV}$ and $533.1 \mathrm{eV}$ representing $\mathrm{C}=\mathrm{O}$ and $\mathrm{C}-\mathrm{O}$, respectively (Fig. 3d). The XPS spectra of Ce3d indicated the presence of a mixedvalence state $\left(\mathrm{Ce}^{3+} / \mathrm{Ce}^{4+}\right)$ in the Ce-MOF, and the ratio of $\mathrm{Ce}^{4+} /$ $\mathrm{Ce}^{3+}$ was found to be $6 \%$ (Fig. 3e). ${ }^{48}$ The peaks at the binding energy values of $881.5 \mathrm{eV}, 886.9 \mathrm{eV}, 900.0 \mathrm{eV}$, and $912.3 \mathrm{eV}$ were associated with $\mathrm{Ce}^{4+}$, while the peaks at $885.0 \mathrm{eV}$ and $903.7 \mathrm{eV}$ were associated with $\mathrm{Ce}^{3+} \cdot{ }^{48}$ The XPS analysis confirmed the successful formation of Ce-MOF (Fig. 3f).

The FT-IR spectra of the organic linker $\mathrm{H}_{3} \mathrm{NTB}$ and AU-1 confirmed the formation of coordination bonds within the framework (Fig. S6, ESI $\dagger$ ). The FT-IR spectrum of $\mathrm{H}_{3} \mathrm{NTB}$ showed a strong vibrational peak at the wavenumber of $1693 \mathrm{~cm}^{-1}$ referring to the carbonyl group $\mathrm{C}=\mathrm{O}$ (Fig. S7, ESI $\dagger$ ). After coordination with $\mathrm{Ce}^{3+}$, the organic linker exhibited strong absorption peaks at wavenumbers $1595 \mathrm{~cm}^{-1}$ and $1410 \mathrm{~cm}^{-1}$ corresponding to the asymmetric and symmetric stretching vibrations of $\mathrm{COO}^{-}$(Fig. S7, ESI $\dagger$ ). The results from the FT-IR analysis confirmed the complete activation of the compound (Fig. S7, ESI $\dagger$ ). AU-1 had a hexagonal nanorod morphology, as confirmed by the TEM image (Fig. S8, ESI $\dagger$ ). The material weakly diffracted in electron diffraction (Fig. S9, ESI $\dagger$ ). The morphology of the Ce-MOF was confirmed using SEM images (Fig. S10, ESI $\dagger$ ). The SEM images showed rods with a hexagonal morphology at the end (Fig. S10, ESI $\dagger$ ).

To investigate the thermal stability of AU-1, TGA was performed in the range of $25-700{ }^{\circ} \mathrm{C}$ under an air atmosphere (Fig. 2b). It could be concluded that the material (empirical
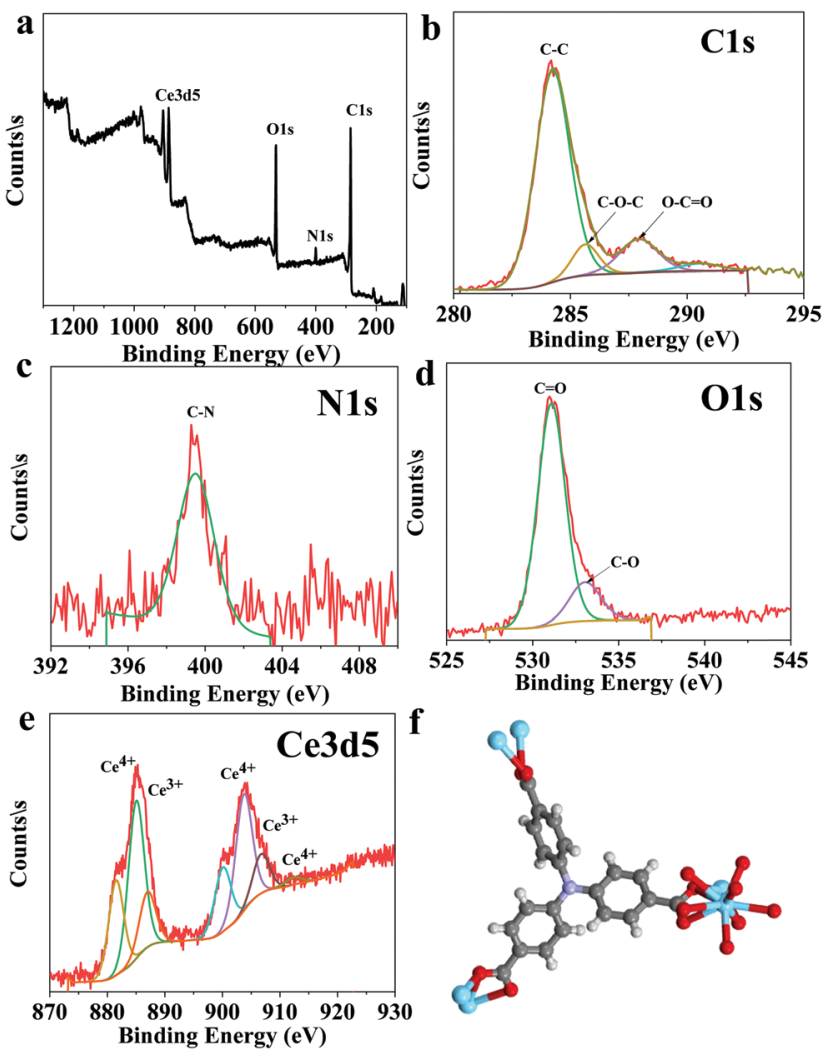

Fig. 3 XPS analysis of the Ce-MOF: (a) element survey, (b) C1s, (c) N1s, (d) O1s, (e) Ce3d5, and (f) the chemical structure of the Ce-MOF. 
formula, $\mathrm{C}_{21} \mathrm{H}_{12} \mathrm{CeNO}_{7}$, and molecular weight $530.44 \mathrm{~g} \mathrm{~mol}^{-1}$ ) was stable up to $390{ }^{\circ} \mathrm{C}$. The first weight loss $\left(40-183{ }^{\circ} \mathrm{C}, 12 \mathrm{wt} \%\right)$ occurred because of the removal of the guest molecules. In the temperature range of $300-330{ }^{\circ} \mathrm{C}$, the second weight loss took place due to the removal of the occluded DMF molecules. Above the temperature of $370{ }^{\circ} \mathrm{C}$, the material started to decompose due to the loss of the framework linker. The residual value $32.2 \%$ corresponded to $\mathrm{CeO}_{2}$ (calculated value $=32.5 \%$ ). The TGA curve confirmed the chemical formula of $\mathbf{A U}-\mathbf{1}\left(\mathrm{C}_{21} \mathrm{H}_{12} \mathrm{CeNO}_{7}\right)$. The differential thermal analysis (DTA) showed a major exothermic band at $380{ }^{\circ} \mathrm{C}$ corresponding to linker volatilization (Fig. 2b).

\section{Biological activity of AU-1}

Antifungal activity of AU-1: disruption and inhibiting recolonization of fungi. The antifungal properties of the Ce-MOF were investigated against five fungal pathogens, namely Candida albicans, Aspergillus niger, Aspergillus flavus, Aspergillus terreus, Candida albicans, and Rhodotorula glutinis. C. Albicans is a dimorphic fungus i.e. forms both yeast and filamentous cells. A. niger is a filamentous Ascomycete fungus that can infect humans and plants and cause food contamination or fermentation. It can be found in bakery products, cheeses, and preserved fruits. A. flavus is a pathogenic fungus that can colonize cereal grains, legumes, and tree nuts. A. terreus is a mold that can be found in soil. Both A. flavus and A. terreus are saprotrophic fungi. $R$. glutinis colonizes foods, animals, and environment-based materials. All these fungi are spread worldwide. Thus, they were used as models to investigate the antifungal activity of the Ce-MOF, AU-1.

The antifungal activity of AU-1 against A. niger, A. flavus, A. terreus, C. Albicans and $R$. glutinis is presented in Fig. 4, 5 and Fig. S11-S13 (ESI $\dagger$ ). The bioactivity of AU-1 was evaluated based on dry mass (Fig. 4a), soluble proteins (SP, Fig. 4b), microscopic images (Fig. 5), and colony-forming units (CFU, Fig. S11-S13, ESI $\dagger$ ). The activities were measured using different concentrations of AU-1 (0-40 $\left.\mu \mathrm{g} \mathrm{mL}^{-1}\right)$.

The dry mass of fungi upon incubation with AU-1 is reported (Fig. 4a). The dry mass decreased with an increase in the AU-1 concentration (Fig. 4a). The dry mass of A. flavus $\left(12.55 \pm 0.39 \mathrm{~g} \mathrm{~L}^{-1}\right)$, A. niger $\left(19.05 \pm 0.68 \mathrm{~g} \mathrm{~L}^{-1}\right)$, A. terreus $\left(15.45 \pm 0.17 \mathrm{~g} \mathrm{~L}^{-1}\right), C$. Albicans $\left(1.13 \pm 0.02 \mathrm{~g} \mathrm{~L}^{-1}\right)$, and $R$. glutinis $\left(1.06 \pm 0.03 \mathrm{~g} \mathrm{~L}^{-1}\right)$ decreased to $6.65 \pm 0.14 \mathrm{~g} \mathrm{~L}^{-1}, 8.38 \pm 0.24 \mathrm{~g} \mathrm{~L}^{-1}, 3.49 \pm 0.09 \mathrm{~g} \mathrm{~L}^{-1}$, $0.97 \pm 0.05 \mathrm{~g} \mathrm{~L}^{-1}$, and $0.98 \pm 0.02 \mathrm{~g} \mathrm{~L}^{-1}$, respectively (Fig. 4a). The change in dry mass was higher for A. flavus, A. niger, and A. terreus, compared to $C$. Albicans and $R$. glutinis (Fig. 4a). The decrease in dry mass was due to the antifungal activity of Ce-MOF, which inhibited fungal growth and disrupted their components. AU-1 showed high antifungal activity and inhibited the growth of the pathogenic fungi with inhibition efficiencies between $7.55-77.41 \%$ (Fig. 4a).

The soluble proteins of the fungi after treatment with different concentrations of AU-1 were estimated (Fig. 4b). The amount of soluble proteins ( $\mathrm{mg} \mathrm{g}^{-1}$ fresh weight) increased with an increase in the concentration of AU-1 (Fig. 4b). The maximum amount of soluble proteins was observed at the highest concentration of AU-1, indicating the disruption of fungal cells due to the oxidative stress generated by the Ce-MOF (Fig. 4b). Thus, the amount of soluble proteins is increased upon treatment with Ce-MOF (Fig. 4b).

The effect of the concentration $\left(0-40 \mu \mathrm{g} \mathrm{mL}{ }^{-1}\right)$ of $\mathbf{A U}-\mathbf{1}$ on the morphology of pathogenic fungi was tested (Fig. 5). There was no dramatic change in the morphology of $A$. niger, $C$. Albicans and $R$. glutinis at all concentrations. On the other hand, changes in the morphology of A. flavus and A. terreus were observed at a high concentration of AU-1 $\left(40 \mu \mathrm{g} \mathrm{mL} \mathrm{m}^{-1}\right.$, Fig. 5) in the conidiophores, vesicles, and phialides. These morphological changes confirmed the disruption of cell wall and release of content due to the toxic effect of high concentrations of the Ce-MOF. These changes also verified the alterations in the physiology and metabolic activities of the cells. These fungal deformations were attributed to the toxic effects at high concentrations due to the accumulation of reactive oxygen species (ROS) in the cells, which may lead to cell death.

The colony-forming units (CFU) of the fungi were also used to evaluate the cytotoxicity of the Ce-MOF (Fig. S11-S13, ESI $\dagger$ ). The spores generated after the treatment with Ce-MOF were still viable and could grow again in the medium (Fig. S11, ESI $\dagger$ ). However, the total counts of the spores and yeast cells decreased dramatically compared with those from the non-treated samples (Fig. S13, ESI $\dagger$ ). Data analysis for A. flavus, A. niger, A. terreus, C. Albicans, and R. glutinis showed the efficiencies of $93.3 \%$, 96.3\%, 99.3\%, 93.3\%, and 96\%, respectively (Fig. S13, ESI $\dagger$ ). The CFU method revealed that the Ce-MOF exhibited high antifungal activity (Fig. S13, ESI $\dagger$ ), which varied between the different fungi due to their properties. However, the $6 \%$ difference in efficiency among them was insignificant, indicating that the Ce-MOF is a broad-spectrum antifungal agent (Fig. S13, ESI $\dagger$ ).
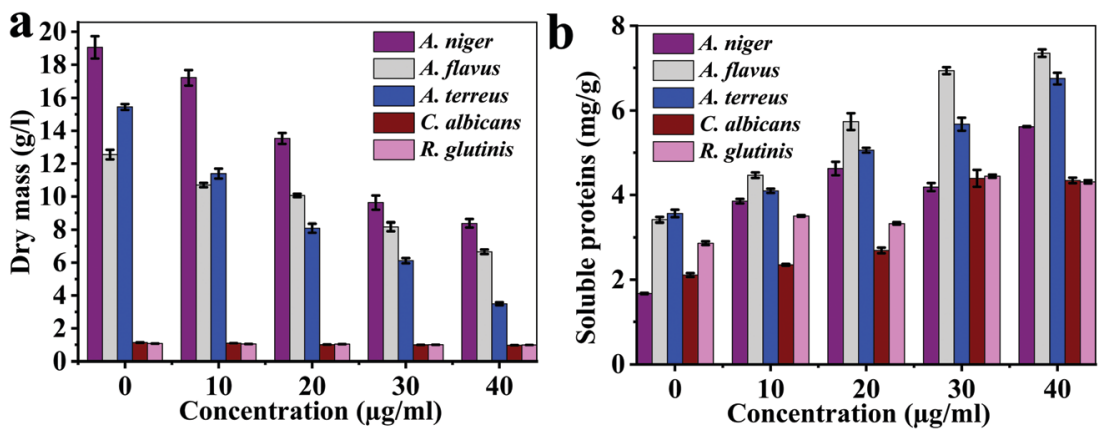

Fig. 4 (a) Dry mass and (b) soluble proteins of the fungi upon treatment with different concentrations of AU-1 (0-40 $\left.\mu \mathrm{g} \mathrm{mL} \mathrm{L}^{-1}\right)$. 


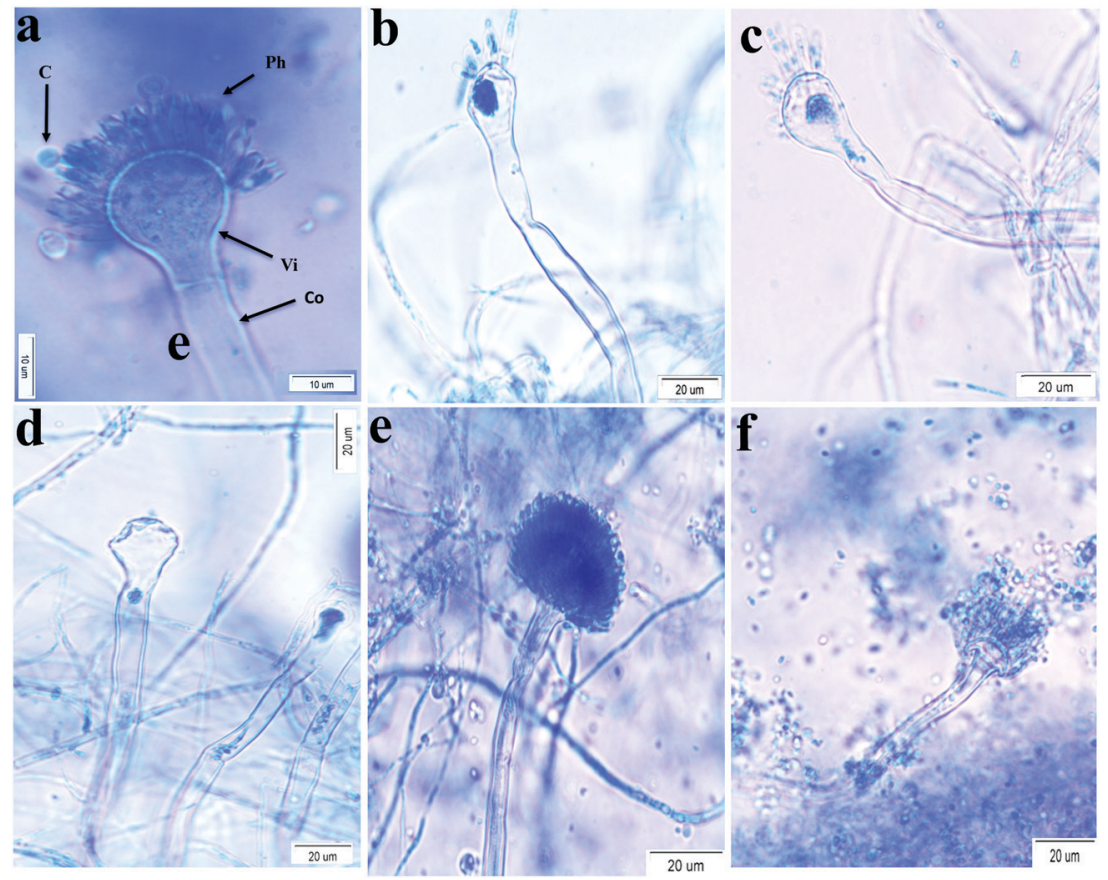

Fig. 5 Microscopic images of $A$. flavus in (a) the medium and (b-d) after incubation with $\mathbf{A U}-\mathbf{1}\left(10,20\right.$, and $40 \mu \mathrm{mL}^{-1}$, respectively); images of $A$. terreus in (e) the medium and (f) after incubation with AU-1 $\left(40 \mu \mathrm{g} \mathrm{mL}^{-1}\right)$. Co - conidiophore; Vi - vesicle; Ph - phialid; C - conidia.

Enzymatic activity of AU-1 against fungi: mechanism of antifungal activity. The antifungal activity of AU-1 could be due to the well-known enzymatic activity of cerium-based nanomaterials. Thus, the enzymatic activity of AU-1 was recorded via measuring the total antioxidant (TA), catalase (CAT), superoxide dismutase (SOD), and peroxidase (POD) activities (Fig. 6a-d).
The total antioxidant values $\left(\mu \mathrm{g} \mathrm{g}^{-1}\right.$ protein) reached the maximum of $4.44 \pm 0.06\left(30 \mu \mathrm{g} \mathrm{mL}{ }^{-1}\right)$ for A. flavus, $4.55 \pm 0.09$ $\left(40 \mu \mathrm{g} \mathrm{mL}{ }^{-1}\right)$ for $A$. niger, $7.34 \pm 0.19\left(40 \mu \mathrm{g} \mathrm{mL}^{-1}\right)$ for A. terreus, $8.03 \pm 0.31\left(30 \mu \mathrm{g} \mathrm{mL}^{-1}\right)$ for C. Albicans, $8.88 \pm 0.05\left(40 \mu \mathrm{g} \mathrm{mL}^{-1}\right)$ for $R$. glutinis, which were much lower compared with those of the control samples: $2.08 \pm 0.16 \mathrm{mg} \mathrm{g}^{-1}, 2.53 \pm 0.22 \mathrm{mg} \mathrm{g}^{-1}, 2.63 \pm$ $0.11 \mathrm{mg} \mathrm{g}^{-1}, 6.64 \pm 0.35 \mathrm{mg} \mathrm{g}^{-1}$, and $4.88 \pm 0.24 \mathrm{mg} \mathrm{g}^{-1}$ protein,
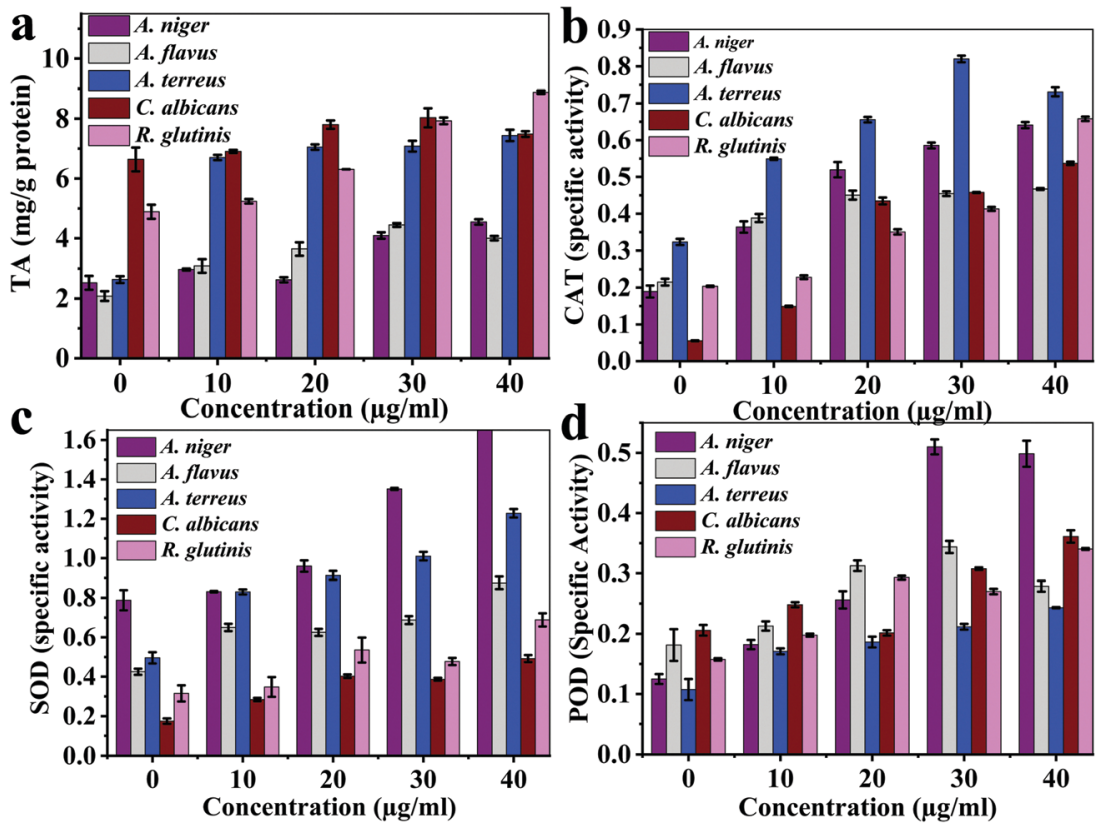

Fig. 6 The multi-enzymatic activity of the Ce-MOF: (a) total antioxidant activity, (b) catalase enzyme, (c) superoxide dismutase enzyme, and (d) peroxidase enzyme. 


$$
\begin{array}{lll}
\mathrm{O}_{2}{ }^{-}+\mathrm{Ce}^{4+} & \\
\mathrm{O}_{2}{ }^{--}+\mathrm{Ce}^{3+}+2 \mathrm{H}^{+} & \longrightarrow & \mathrm{O}_{2}+\mathrm{Ce}^{3+} \\
\mathrm{H}_{2} \mathrm{O}_{2}+\mathrm{Ce}^{4+}
\end{array}
$$

Fig. 7 Superoxide dismutation in the $\mathbf{A U}-\mathbf{1}$ framework.

respectively (Fig. 6a). The maximum catalase enzyme (CAT) values were $0.46 \pm 0.002,0.64 \pm 0.008,0.82 \pm 0.009,0.54 \pm 0.004$, and $0.66 \pm 0.006$ specific units for A. flavus, A. niger, A. terreus, C. Albicans, and R. glutinis, respectively (Fig. 6b). The maximum superoxide dismutase enzyme (SOD) specific activity values were $0.88 \pm 0.03,1.68 \pm 0.01,1.23 \pm 0.21,0.49 \pm 0.01$, and $0.69 \pm 0.03$ for A. flavus, A. niger, A. terreus, C. Albicans, and $R$. glutinis, respectively (Fig. 6c). The maximum peroxidase enzyme (POD) activity of AU-1 values were $0.34 \pm 0.01,0.51 \pm 0.01,0.24 \pm 0.001$, $0.36 \pm 0.01$, and $0.34 \pm 0.001 \mathrm{U} \mathrm{g}^{-1}$ protein for $A$. flavus, A. niger, A. terreus, C. Albicans, and R. glutinis, respectively (Fig. 6d). Thus, AU-1 generated oxidative stress in the fungal cells and further caused generation of reactive oxygen species (ROS), which damaged the cell membrane.

There is no single mechanism that can support the redox regeneration mechanism of a Ce-MOF, such as AU-1. ${ }^{49}$ However, X-ray photoelectron spectroscopy (XPS) revealed the presence of both $\mathrm{Ce}^{3+}$ and $\mathrm{Ce}^{4+}$ ions in the framework of $\mathbf{A U}-1 .^{50}$ It has been reported that cerium-based materials with a high ratio of $\mathrm{Ce}^{3+} /$ $\mathrm{Ce}^{4+}$ exhibited better SOD activity. ${ }^{51,52}$ We also observed the formation of $\mathrm{H}_{2} \mathrm{O}_{2}$, which is one of the products of SOD-catalyzed reactions. The cerium center with two oxidation states $\left(\mathrm{Ce}^{4+}\right.$ and $\mathrm{Ce}^{3+}$ ) was intrinsically formed during the synthesis of AU-1. A mechanism explaining the efficiency of AU-1 is proposed in Fig. 7 without involving the auto-regeneration of $\mathrm{Ce}^{3+}$ on $\mathbf{A U}-\mathbf{1}$.

To support the antioxidant activity, the UV-Vis absorption spectra of Ce-MOF without and with a mild oxidant e.g. hydrogen peroxide $\left(\mathrm{H}_{2} \mathrm{O}_{2}\right)$ were recorded (Fig. 8). The Ce-MOF solution displayed absorption at wavelengths $246 \mathrm{~nm}$ and $356 \mathrm{~nm}$ corresponding to $\pi-\pi^{*}$ and $n-\pi^{*}$, respectively (Fig. 8a). ${ }^{53,54}$ The absorption intensities of both peaks increased with time (Fig. 8b). The increment in the absorbance was due to the oxidation of the $\mathrm{Ce}$ nodes upon interaction with $\mathrm{H}_{2} \mathrm{O}_{2}$. The absorbance intensity reached a steady-state within a very short time $(10 \mathrm{~min})$. This observation indicated the fast response of the Ce-MOF toward the oxidant, namely $\mathrm{H}_{2} \mathrm{O}_{2}$ (Fig. 8b).

MOFs are effective antifungal agents (Table 1). Copper-based MOFs, such as Cu-BTC (BTC $=1,3,5$-benzenetricarboxylate) $)^{55}$ and HKUST-1, ${ }^{56}$ have been reported as antifungal agents against C. Albicans and Saccharomyces cerevisiae, respectively (Table 1). Cu-BTC could inhibit the spores of C. Albicans, Fusarium oxysporum, and Aspergillus oryzae up to $100 \%$ and $30 \%$ (for $F$. oxysporum, A. oryzae), without significant activity against $A$. niger even after 7 days of treatment (Table 1). ${ }^{55}$ The antifungal activity of $\mathrm{Co}(\mathrm{II})$-coordination polymers (Co-CPs) containing glutarates and bipyridyl ligands was shown to be the highest at an optimum concentration of $2.0 \mathrm{mg} \mathrm{mL}$
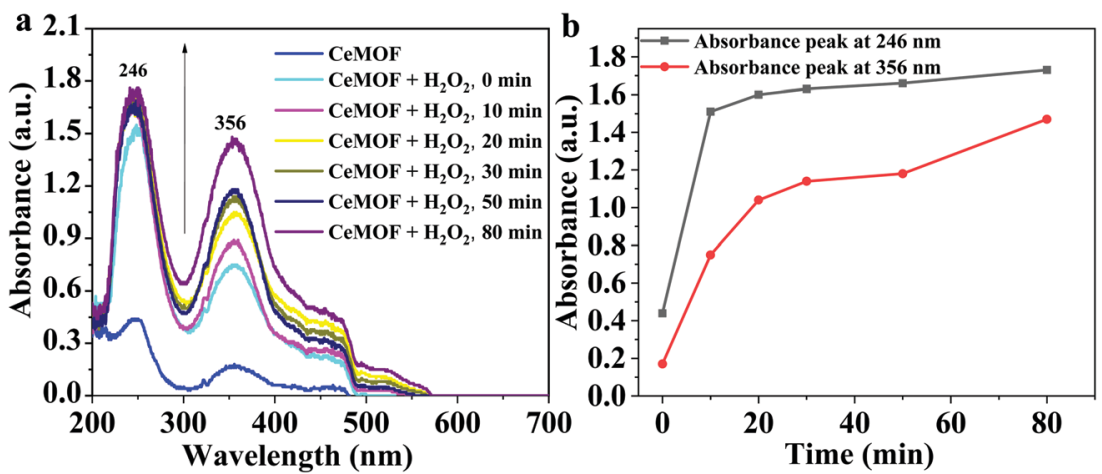

Fig. 8 (a) UV-Vis absorption spectra of Ce-MOF without and with $\mathrm{H}_{2} \mathrm{O}_{2}$ over time, and (b) the absorbance intensities at wavelengths 246 nm and $356 \mathrm{~nm}$.

Table 1 A summary of MOF-based nanomaterials as antifungal agents

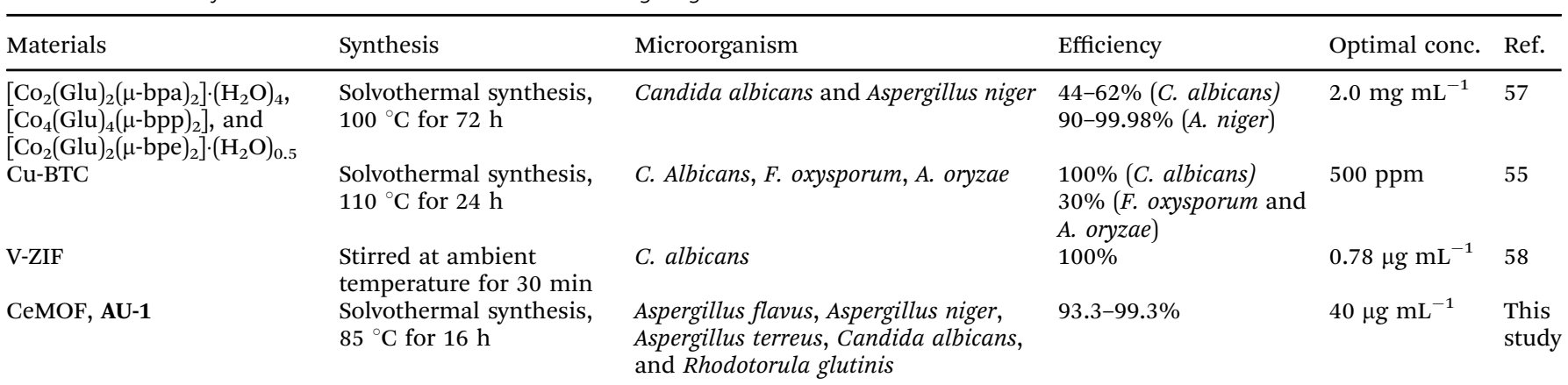

Notes: Glu, glutarate; bpy, 4,4'-bipyridine; bpe, 1,2-bis(4-pyridyl)ethylene; bpymh, $N, N^{\prime}$-bis((pyridine-4-ylmethylene)hydrazine). 
(Table 1). ${ }^{57}$ In this study, the reported inhibition rates were 44-62\% and $90-99.98 \%$ for A. niger and C. Albicans (Table 1). ${ }^{57}$ The antifungal activity of Co-MOF was due to the generation of reactive nitrogen oxide species (NO) and $\mathrm{H}_{2} \mathrm{O}_{2}$. The Ce-MOF exhibited high activity at a comparatively low concentration of $40 \mu \mathrm{g} \mathrm{mL}{ }^{-1} .^{57}$ Voriconazole-incorporated zinc 2-methylimidazolates frameworks (V-ZIF) exhibited high penetration of C. Albicans biofilms with an antifungal efficiency of $100 \%$ (Table 1). ${ }^{58}$ MOF-based antifungal agents are promising and offer several advantages, such as high efficiency, low agent loading, and the possibility to be modified with other agents, such as nanoparticles (Table 1). AU-1 showed enzyme-like activities, including peroxidase-like activity, and could kill fungi with 93.3-99.3\% efficiency (Table 1). Thus, it could prevent the recolonization of the fungi. The cerium-based MOF exhibited excellent ROS-scavenging activity and mimicked superoxide dismutase and catalase. ${ }^{59}$ Thus, it can be used further for biomedical applications, such as biocatalysis, biosensing, and drug delivery.

\section{Conclusions}

The solvothermal synthesis of a Ce-MOF, AU-1, was achieved using a tri-topic carboxylic linker and cerium as the metal center. The material had a crystalline phase with good thermal stability up to $380{ }^{\circ} \mathrm{C}$. It contained Ce in mixed-valence states $\left(\mathrm{Ce}^{4+}\right.$ and $\mathrm{Ce}^{3+}$ ). The antifungal activity of AU-1 was evaluated using different bioanalytical methods, including dry mass, soluble proteins, microscopic images, and colony-forming units. The data revealed high species-dependent antifungal activity of the Ce-MOF. The antifungal activity of the Ce-MOF increased with an increase in material concentration. AU-1 possessed good enzymatic activities, such as superoxide dismutation, catalase, and peroxidase, and may be useful as a new anticancer, antioxidant, and antimicrobial platform for other biomedical applications. This work promotes the application of MOFs in nanomedicine and biomaterials.

\section{Conflicts of interest}

There are no conflicts to declare.

\section{Acknowledgements}

The authors thank the Ministry of Higher Education and Scientific Research (Egypt), Assiut University, and Institutional Review Board (IRB) of the Faculty of Science at Assiut University, Egypt for support.

\section{References}

1 H.-C. Zhou, J. R. Long and O. M. Yaghi, Chem. Rev., 2012, 112, 673-674.

2 J. Lee, O. K. Farha, J. Roberts, K. A. Scheidt, S. T. Nguyen and J. T. Hupp, Chem. Soc. Rev., 2009, 38, 1450.

3 Z.-Y. Gu, J. Park, A. Raiff, Z. Wei and H.-C. Zhou, ChemCatChem, 2014, 6, 67-75.
4 X.-P. Wu, L. Gagliardi and D. G. Truhlar, J. Am. Chem. Soc., 2018, 140, 7904-7912.

5 H. N. Abdelhamid, Mater. Today Chem., 2020, 15, 100222.

6 A. A. Kassem, H. N. Abdelhamid, D. M. Fouad and S. A. Ibrahim, Int. J. Hydrogen Energy, 2019, 44, 31230-31238.

7 K.-J. Kim, H.-J. Kim, H.-G. Park, C.-H. Hwang, C. Sung, K.-S. Jang, S.-H. Park, B.-G. Kim, Y.-K. Lee, Y.-H. Yang, J. H. Jeong and Y.-G. Kim, Sci. Rep., 2016, 6, 24489.

8 H. N. Abdelhamid, Z. Huang, A. M. El-Zohry, H. Zheng and X. Zou, Inorg. Chem., 2017, 56, 9139-9146.

9 H. N. Abdelhamid, Microchim. Acta, 2018, 185, 200.

10 H. E. Emam, H. N. Abdelhamid and R. M. Abdelhameed, Dyes Pigm., 2018, 159, 491-498.

11 M. N. Goda, H. N. Abdelhamid and A. E.-A. A. Said, ACS Appl. Mater. Interfaces, 2020, 12, 646-653.

12 A. A. Kassem, H. N. Abdelhamid, D. M. Fouad and S. A. Ibrahim, Microporous Mesoporous Mater., 2020, 305, 110340.

13 H. N. Abdelhamid, A. M. El-Zohry, J. Cong, T. Thersleff, M. Karlsson, L. Kloo and X. Zou, R. Soc. Open Sci., 2019, 6, 190723.

14 L. Valencia and H. N. Abdelhamid, Carbohydr. Polym., 2019, 213, 338-345.

15 H. N. Abdelhamid, M. Wilk-Kozubek, A. M. El-Zohry, A. Bermejo Gómez, A. Valiente, B. Martín-Matute, A.-V. Mudring and X. Zou, Microporous Mesoporous Mater., 2019, 279, 400-406.

16 A. F. Abdel-Magied, H. N. Abdelhamid, R. M. Ashour, X. Zou and K. Forsberg, Microporous Mesoporous Mater., 2019, 278, 175-184.

17 S. Sultan, H. N. Abdelhamid, X. Zou and A. P. Mathew, Adv. Funct. Mater., 2018, 1805372.

18 H. N. Abdelhamid, M. Dowaidar and Ü. Langel, Microporous Mesoporous Mater., 2020, 110200.

19 H. N. Abdelhamid, Macromol. Chem. Phys., 2020, 221, 2000031.

20 H. N. Abdelhamid, M. Dowaidar, M. Hällbrink and Ü. Langel, Microporous Mesoporous Mater., 2020, 300, 110173.

21 H. N. Abdelhamid, Dalton Trans., 2020, 49, 4416-4424.

22 X. Zhang, G. Li, D. Wu, X. Li, N. Hu, J. Chen, G. Chen and Y. Wu, Biosens. Bioelectron., 2019, 137, 178-198.

23 W. Song, B. Zhao, C. Wang, Y. Ozaki and X. Lu, J. Mater. Chem. B, 2019, 7, 850-875.

24 Z. Liu, F. Wang, J. Ren and X. Qu, Biomaterials, 2019, 208, 21-31.

25 X. Li, M. Qi, C. Li, B. Dong, J. Wang, M. D. Weir, S. Imazato, L. Du, C. D. Lynch, L. Xu, Y. Zhou, L. Wang and H. H. K. Xu, J. Mater. Chem. B, 2019, 7, 6955-6971.

26 L. Luo, L. Huang, X. Liu, W. Zhang, X. Yao, L. Dou, X. Zhang, Y. Nian, J. Sun and J. Wang, Inorg. Chem., 2019, 58, 11382-11388.

27 C. J. Alexopoulos, C. W. Mims and M. Blackwell, Introductory Mycology, Wiley, New York, 4th edn, 1996, p. 868.

28 The Fifth Kingdom, http://www.mycolog.com/fifthtoc.html, (accessed 8 December 2019).

29 H. Ogawa, M. Fujimura, Y. Takeuchi and K. Makimura, Clin. Exp. Allergy, 2012, 42, 1540-1541.

30 S. N. Baxi, J. M. Portnoy, D. Larenas-Linnemann, W. Phipatanakul, C. Barnes, S. Baxi, C. Grimes, W. E. Horner, 
K. Kennedy, D. Larenas-Linnemann, E. Levetin, J. D. Miller, W. Phipatanakul, J. M. Portnoy, J. Scott and P. B. Williams, J. Allergy Clin. Immunol. Pract., 2016, 4, 396-404.

31 C. J. Schwab and D. C. Straus, Adv. Appl. Microbiol., 2004, 55, 215-238.

32 M. T. Hedayati, A. C. Pasqualotto, P. A. Warn, P. Bowyer and D. W. Denning, Microbiology, 2007, 153, 1677-1692.

33 J. M. Achkar and B. C. Fries, Clin. Microbiol. Rev., 2010, 23, 253-273.

34 M. Ramasamy and J. Lee, BioMed Res. Int., 2016, 2016, 1-17.

35 P. Zhu, L. Zhou, Y. Song, L. Cai, M. Ji, J. Wang, G. Ruan and J. Chen, J. Mater. Chem. B, 2020, 8, 4899-4907, DOI: 10.1039/ D0TB00106F.

36 D. M. O’Brien, C. Vallieres, C. Alexander, S. M. Howdle, R. A. Stockman and S. V. Avery, J. Mater. Chem. B, 2019, 7, 5222-5229.

37 I. Franco Castillo, E. García Guillén, J. M. de la Fuente, F. Silva and S. G. Mitchell, J. Mater. Chem. B, 2019, 7, 6412-6419.

38 Y. N. Albayaty, N. Thomas, P. D. Ramírez-García, T. P. Davis, J. F. Quinn, M. R. Whittaker and C. A. Prestidge, J. Mater. Chem. B, 2020, 8, 1672-1681.

39 H. N. Abdelhamid, Future Microbiol., 2020, fmb-2019-0260.

40 H. N. Abdelhamid, Nanotoxicity, Elsevier, 2020, pp. 195-214.

41 S. Kumaran, H. N. Abdelhamid, N. Hasan and H.-F. Wu, Nanosci. Nanotechnol., 2020, 10, 80-85.

42 Z. Liu, J. Liu, R. Wang, Y. Du, J. Ren and X. Qu, Biomaterials, 2015, 56, 206-218.

43 G. Abd-Elmonsef Mahmoud, A. S. A. Zidan, A. A. M. Aly, H. K. Mosbah and A. B. M. Ibrahim, Appl. Organomet. Chem., 2019, 33, e4740.

44 N. A. Nafady, M. M. K. Bagy, M. H. Abd-Alla, F. M. Morsy and G. A.-E. Mahmoud, Rend. Lincei, 2015, 26, 335-344.
45 S. Espín, E. Martínez-López, P. Jiménez, P. María-Mojica and A. J. García-Fernández, Environ. Res., 2014, 129, 59-68.

46 P. Prieto, M. Pineda and M. Aguilar, Anal. Biochem., 1999, 269, 337-341.

47 Q. Yao, A. Bermejo Gómez, J. Su, V. Pascanu, Y. Yun, H. Zheng, H. Chen, L. Liu, H. N. Abdelhamid, B. MartínMatute and X. Zou, Chem. Mater., 2015, 27, 5332-5339.

48 M. Das, S. Patil, N. Bhargava, J.-F. Kang, L. M. Riedel, S. Seal and J. J. Hickman, Biomaterials, 2007, 28, 1918-1925.

49 C. Xu and X. Qu, NPG Asia Mater., 2014, 6, e90.

50 R. Dalapati, B. Sakthivel, M. K. Ghosalya, A. Dhakshinamoorthy and S. Biswas, CrystEngComm, 2017, 19, 5915-5925.

51 C. Korsvik, S. Patil, S. Seal and W. T. Self, Chem. Commun., 2007, 1056.

52 E. G. Heckert, A. S. Karakoti, S. Seal and W. T. Self, Biomaterials, 2008, 29, 2705-2709.

53 H. N. Abdelhamid, A. Bermejo-Gómez, B. Martín-Matute and X. Zou, Microchim. Acta, 2017, 184, 3363-3371.

54 Y. Yang, K. Shen, J. Lin, Y. Zhou, Q. Liu, C. Hang, H. N. Abdelhamid, Z. Zhang and H. Chen, RSC Adv., 2016, 6, 45475-45481.

55 S. Bouson, A. Krittayavathananon, N. Phattharasupakun, P. Siwayaprahm and M. Sawangphruk, R. Soc. Open Sci., 2017, 4, 170654.

56 C. Chiericatti, J. C. Basilico, M. L. Zapata Basilico and J. M. Zamaro, Microporous Mesoporous Mater., 2012, 162, 60-63.

57 H.-C. Kim, S. Mitra, M. Veerana, J.-S. Lim, H.-R. Jeong, G. Park, S. Huh, S.-J. Kim and Y. Kim, Sci. Rep., 2019, 9, 14983.

58 L. Su, Y. Li, Y. Liu, R. Ma, Y. Liu, F. Huang, Y. An, Y. Ren, H. C. Mei, H. J. Busscher and L. Shi, Adv. Funct. Mater., 2020, 2000537.

59 S. W. Choi and J. Kim, ACS Appl. Nano Mater., 2020, 3, 1043-1062. 